\title{
Haunted by Defeat: Imperial Sexualities, Prostitution, and the Emergence of Postwar Japan
}

\author{
ROBERT KRAMM \\ The University of Hong Kong
}

Following their defeat in World War II, Japan's state authorities
initiated the building of recreational facilities with brothels, bars, cabarets, and restaurants to "comfort" (ian) the Allied military occupiers. "Comfort station" was a euphemism for the institutionalized system of military sex slavery implemented by the Japanese state throughout Asia during the war. In the immediate postwar period, Japanese officials adapted established practices developed during the imperial period about both forced and voluntary prostitution, sexuality, and its regulation to conceptualize a postwar "recreation scheme." They called it a "female floodwall" (onna no bōhatei)—a protective zone to separate the foreign occupation troops from the Japanese population and especially from women and girls. The initiative was aimed at protecting the "national body" (kokutai), a fuzzy concept of identity and unity originating in imperial Japan. With the sudden disintegration of its empire, this initiative helped Japan's authorities establish a new sense of community. Its emergence was shaped by imperial strategies being turned inwards as Japanese society shifted from colonizer to colonized with the imposition of American hegemony.

Gender and sexuality, mediated by Japanese women's bodies, were key elements in this clash between the fall of the Japanese empire and the rise of the U.S. empire which forged the emergence of postwar Japanese nationalism. ${ }^{1}$ This article analyzes the conceptualization and

\footnotetext{
${ }^{1}$ A well established body of scholarship has elaborated on the argument that gender and sexuality are inseparable from empire and nation. See for example, Ann Laura Stoler, Race and the Education of Desire: Foucault's History of Sexuality and the Colonial Order of Things
}

Journal of World History, Vol. 28, Nos. $3 \& 4$

(C) 2017 by University of Hawai'i Press 
organization of the "female floodwall" in the still-imaginary encounter of occupier and occupied during the immediate post-surrender period in the late summer of I945. It focuses on male agents of the Japanese state and entertainment industry who-haunted by defeat-zealously propagated the need to provide sexual outlets for the arriving occupiers and recruit women for this task. Following insights from studies on "entangled memories" in national identity politics, this article underscores that Japan's re-imagined national Self, its post-imperial territorial boundaries, and biopolitical references were, to quote Sebastian Conrad, "the product-and not the precondition-of processes of transnational interaction, exchange and entanglement."

"To be haunted," writes Ann Stoler, "is to be frequented by and possessed by a force that not always bares a proper name" and means being familiar with a place or set of ideas as well as being confronted with a vague, often invisible threat. ${ }^{3}$ Japanese contemporaries at the end of World War II oscillated between these two meanings and were haunted on various levels entailing past and future temporal coordinates. In the midst of defeat they feared the implications of the loss of their empire and were uncertain about their national integrity under threat by the unknown outcome of a foreign military presence. Yet Japan's imperial past remained their point of reference in making sense of the situation. Prostitution as an administrative practice was a key issue for Japanese authorities trying to take control of their situation at this moment of fear and uncertainty. It constituted a discursive order of the Japanese empire that male Japanese agents of the state reinterpreted in the post-surrender period. Prostitution as administrative practice functioned, on the one hand, as a significant interface for the mediation of certain forms of authoritarian bureaucratic

(Durham, NC and London: Duke University Press, I995), 7; Anne McClintock, Imperial Leather: Race, Gender and Sexuality in the Colonial Contest (New York and London: Routledge, I995), 4; Philippa Levine, "Sexuality and Empire," in At Home with the Empire: Metropolitan Culture in the Imperial World, eds. Catherine Hall and Sonya O. Rose (Cambridge: Cambridge University Press, 2006), I23; Antoinette Burton, ed., Gender, Sexuality and Colonial Modernities (London and New York: Routledge, I999); Clare Midgley, ed., Gender and Imperialism (Manchester: Manchester University Press, I998); Sabine Frühstück, "Sexuality and the Nation-State," in A Global History of Sexuality: The Modern Era, eds. Robert Buffington, Eithne Luibhéid, and Donna J. Guy (Oxford: Wiley, 2013), I 8; George L. Mosse, "Nationalism and Respectability: Normal and Abnormal Sexuality in the Nineteenth Century," Journal of Contemporary History I 7 (I982): 22 I-246.

2 Sebastian Conrad, "Entangled Memories: Versions of the Past in Germany and Japan, I 945-200 I," Journal of Contemporary History 38, no. I (2003): 98-99.

${ }^{3}$ Ann Laura Stoler, "Intimidations of Empire: Predicaments of the Tactile and Unseen," in Haunted by Empire: Geographies of Intimacy in North American History, ed. Ann L. Stoler (Durham, NC and London: Duke University Press, 2006), I. 
governance and notions of sexuality, gender, class, and race with continuities from the prewar, wartime, and postwar periods. On the other hand, the discourse on prostitution in defeated Japan established the social and geospatial coordinates of protection from the arriving occupiers which ultimately generated a new understanding of Japan and Japanese belonging. The organization of prostitution and the recruitment of women to work in the newly established "comfort facilities" sustain this significant and signifying shift, through which politicians, bureaucrats, policemen, and entrepreneurs of the entertainment industry repeatedly articulated their male nationalistic desire to protect the newly imagined, "re-masculinized" space of Japan.

\section{Facing the Unspeakable: Fear and Fictionalization in the Wake OF DEFEAT}

The postwar occupation of Japan officially began on September 2, I 945, simultaneously marking the end of the Japanese empire. ${ }^{4}$ It also signaled the rise of the United States as a major political, economic, cultural, and military power in the Asia-Pacific region. The occupation of Japan was crucial in establishing the American worldwide "empire of bases" during the Cold War and beyond. ${ }^{5}$ Setsu Shigematsu and Keith L. Camacho have called the continuing U.S. military presence in Asia an "extension of colonialism," arguing that the United States even appropriated former colonial power structures of the Japanese empire after its defeat. ${ }^{6}$ According to John Dower it was "the last immodest exercise in the colonial conceit known as 'the white man's burden."'7

\footnotetext{
${ }^{4}$ However, the emphasis on a supposedly decisive break in 1945 ignores the multiple experiences of Japan's empire, war, and its legacy throughout East Asia, Southeast Asia and the Asia-Pacific region. Arif Dirlik, "Trapped in History' on the Way to Utopia: East Asia's 'Great War' Fifty Years Later," in Perilous Memories: The Asia-Pacific War(s), eds. Takashi Fujitani, Geoffrey M. White and Lisa Yoneyama (Durham, NC and London: Duke University Press, 2001), 300-304.

5 Chalmers Johnson, The Sorrows of Empire: Militarism, Secrecy, and the End of the Republic (New York: Metropolitan Books, 2004), I 5I; Catherine Lutz, The Empire of Bases: The Global Struggle against U.S. Military Posts (New York: New York University Press, 2009); Maria Höhn and Seungsook Moon, eds., Over There: Living with the U.S. Military Empire from World War Two to the Present (Durham, NC and London: Duke University Press, 2010).

6 Setsu Shigematsu and Keith L. Camacho, "Militarized Currents, Decolonizing Futures," in Militarized Currents: Towards a Decolonized Future in Asia and the Pacific, eds. Shigematsu and Camacho (Minneapolis, MN: University of Minnesota Press, 2010), xv (italics in the original).

7 John W. Dower, Embracing Defeat: Japan in the Wake of World War II (New York: W. W. Norton, 1999), 23.
} 
Indeed, the American occupation of Japan created cultural and social patterns of differentiation which were common in colonial settings and imperial formations, among them the sexual encounter between predominantly white men and women of color, often framed by sex work. ${ }^{8}$

The seven years long occupation from I 945 to 1952 has been subject of research in various studies. ${ }^{9}$ Most studies address the atomic bombings on the 6th and 9th of August 1945, the subsequent decision by the Japanese elite's to surrender, and Emperor Hirohito's public radio broadcast announcing the end the war on August 15, 1945. The twoweek period between Japan's defeat and the first arrival of occupation troops is mostly ignored, appearing as a footnote to remarks on Japan's devastation at the end of the war. ${ }^{10}$ Nonetheless, scholars have raised the issue of why the Japanese people were relatively acquiescent in accepting the drastic change from wartime mobilization toward peacetime occupation. Many evaluations rest implicitly on racist statements about Japanese people's alleged obedience toward their old and new leaders. ${ }^{11}$ On the contrary, this article emphasizes Japanese agency at the end of the war. Japanese state officials, all men, were far from passive spectators. They were actively engaged in designing the encounter with the occupiers on their own terms. For instance, as Barak Kushner has highlighted, Japan's police and bureaucracy, two institutions that had been highly involved in the promotion of the war effort, converted to produce "defeat propaganda" for the public to prepare them for their encounter with the former enemy. ${ }^{12}$ In particular the highly militarized Special Higher Police (Tokubetsu kōtō keisatsu, often only referred to as Tokkō) made arduous efforts to control the post-surrender situation. Their reports revolved around the overwhelming fear of domestic threats, such as potential peasant uprisings or social revolution incited by anarchists, socialists, and communists. Another perceived threat to the

\footnotetext{
${ }^{8}$ Mire Koikari, Pedagogy of Democracy: Feminism and the Cold War in the U.S. Occupation of Japan (Philadelphia, PA: Temple University Press, 2008), I 7-18.

${ }^{9}$ For an overview, see: Dower, Embracing Defeat; Carol Gluck, "Entangling IllusionsJapanese and American Views of the Occupation," in New Frontiers in American-East Asian Relations, ed. Warren I. Cohen (New York: Columbia University Press, I983), I69-235.

${ }^{10}$ Eiji Takemae, Inside GHQ: The Allied Occupation of Japan (New York: Continuum, 2002), 56; Herbert Bix, "Japan's Delayed Surrender: A Reinterpretation," in Hiroshima in History and Memory, ed. Michael J. Hogan (Cambridge: Cambridge University Press, I 996), 80-II 5; Dower, Embracing Defeat, 39. On the atomic bombings, see Lisa Yoneyama, Hiroshima Traces: Time, Space, and the Dialectic of Memory (Berkeley, CA: University of California Press, 1999).

${ }^{11}$ For a critique, see Takashi Fujitani, Race for Empire: Koreans as Japanese and Japanese as Americans during World War II (Berkeley, CA: University of California Press, 20 I I), I 4-I 5.

${ }_{12}$ Barak Kushner, The Thought War: Japanese Imperial Propaganda (Honolulu: University of Hawai'i Press, 2006), ı69-1 75.
} 
maintenance of "public peace" (chian) was from overseas. Members of the Tokkō feared the arrival of foreign soldiers who were believed to endanger the Japanese people, especially Japanese women. ${ }^{13}$

Anxiety and uncertainty about the arrival of the Allied occupation forces circulated widely in defeated Japan. Unlike the defeat of Nazi Germany, where foreign soldiers were already present at the time of surrender, in Japan rumors about violent revenge and rape by foreign troops spread even though they were not yet physically present in the country. ${ }^{14}$ These rumors stoked fear among the civilian population and encouraged women and children to hide in the countryside far away from the arriving occupation forces. In the most extreme scenarios, some rumors predicted that the foreign soldiers would violate and rape all Japanese women and force them to become their concubines, while all Japanese men would be enslaved, killed, and/or castrated. ${ }^{15}$ In Kanagawa prefecture, where the Allied occupation forces were supposed to initially enter Japan, local administrators advised the precautionary evacuation to the countryside of all women and children, including their own female staff. ${ }^{16}$ In Tokyo, the Metropolitan Police Department warned that public opinion would be dominated by a "seditious uncertainty" (fuan dōyō) based on rumors of violent acts of revenge by the arriving occupation forces. The police report used expressions such as fujo bōkō, which explicitly means physical-sexual violence against women. It concluded with the suggestion to establish "comfort facilities" (ian goraku shisetsu) for the occupation troops in order to limit sexual violence. ${ }^{17}$ The rumors, official announcements, and reports were thus closely related to fears of physical violence

${ }^{13}$ Kentarō Awaya, Gendaishi hakkutsu (Tokyo: Otsukishoten, I996), 53, 67; Kentarō Awaya and Takane Kawashima, eds., Haisenji zenkoku chian jōhō, Vols. I-7 (Tokyo: Nihon tosho sentā, 1994). On the history of the Tokkō, see: Elise K. Tipton, The Japanese Police State: The Tokko in Interwar Japan (Honolulu: University of Hawai'i Press, I99I).

${ }^{14}$ On defeated Nazi-Germany and the encounter between civilians and the Red Army, see: Atina Grossmann, Jews, Germans, and Allies: Close Encounters in Occupied Germany (Princeton, NJ: Princeton University Press, 2006).

15 Setsuko Inoue, Senryōgun ianjo: Kokka ni yoru baishun shisetsu (Tokyo: Sinhyōron, I 995), ıо; Meiko Yamada, Senryōgun ianfu: Kokusaku baishun no onnatachi no higeki (Tokyo: Kōjinsha, I992), 9-12; Masayo Duus, Haisha no okurimono: Tokushu ian shisetsu RAA o meguru senryōshi no sokumen (Tokyo: Kōdansha, I985), I9-20; Awaya and Kawashima, "Haisen hisenryō: kokumin kakusō no ishiki," in Haisenji, Vols. I, I2, and I8; Awaya, Gendaishi, 67.

16 "Kikisugita Joshi Sokai: Kanagawa-ken de kairan-ban kara konran maneku," Asahi Shinbun, August 19, 1945. And also the Kanagawa police department sustained the possibility of "violence, looting and so on upon the invasion." Kanagawa-ken keisatsu, "Shinchū ni taisuru hankyō to taisaku," in Haisenji, Vol. 2, I 7o.

${ }^{17}$ Keishichō, "Tōmen no mondai ni taisuru shominsō no dōkō," in Shiryō nihon gendaishi, Vol. 2, ed. Kentarō Awaya (Tokyo: Ōtsugi Shoten, I980), I49-I5I. 
generally perceived as sexual violence against women. This gendered threat of the imminent arrival of the occupation forces is deeply inscribed into the records of Japanese bureaucrats, politicians, and policemen. Their anxiety of foreign male soldiers' sexual aggression and of not being able to protect Japanese women from mass-rape by foreign soldiers - an unsubstantiated fear, in retrospect ${ }^{18}$ — was likewise deeply gendered and echoed their anxiety about their loss of manhood following military defeat. Studies on the interrelation of war, sexuality, and masculinity in Western Europe during the First World War, Nazioccupied Soviet Union, ${ }^{19}$ and the aftermath of the Vietnam War ${ }^{20}$ have shown how idealized forms of soldiers' masculinity could be enforced but also shattered by first-hand experiences of wartime violence. In postsurrender Japan, however, the initiators of the "female floodwall" feared emasculation through an imagined yet physically absent enemy. Their anxiety constituted a discourse in which prostitution was appropriated necessary to prevent rape and other violent assaults.

Rumors, official reports, and public announcements at the end of the war and their production of "uncertain knowledge," 21 to borrow a term from Sebastian Jobs, show how male anxiety at the end of the war was channeled into the administrative practice of conceptualizing and organizing prostitution for the occupiers. Previous research has convincingly argued that the idea to set up a broad prostitution scheme to "comfort" the occupiers did not predominantly aim at the protection of individual Japanese subjects but to secure the kokutai. ${ }^{22}$ It is usually claimed that the conceptualization of prostitution in post-surrender Japan derived more or less singularly from Japan's wartime comfort women system, which had been an integral part of Japan's imperial expansion and aggression. ${ }^{23}$ Indeed many similarities

18 Brian P. Walsh, "The Rape of Tokyo: Legends of Mass Sexual Violence and Exploitation During the Occupation of Japan" (PhD diss., Princeton University, 20r6).

19 Jason Crouthamel, An Intimate History of the Front: Masculinity, Sexuality, and German Soldiers in the First World War (New York: Palgrave Macmillan, 2014), 62; Regina Mühlhäuser, Eroberungen: Sexuelle Gewalttaten und intime Beziehungen deutscher Soldaten in der Sowjetunion, 1941-1945 (Hamburg: Hamburger Edition, 2010), 30, 375.

20 This mechanism has been discussed widely for the Vietnam War in the United States: Melissa T. Brown, Enlisting Masculinity: The Construction of Gender in US Military Recruiting Advertising during the All-Volunteer Force (Oxford: Oxford University Press, 2012), 23; J. William Gibson, "Redeeming Vietnam: Techno-Thriller Novels of the I980s," Cultural Critique I9 (I99I): I82.

21 Sebastian Jobs, "Uncertain Knowledge," Rethinking History I 8 (2014): 2-3.

22 Masayo Duus, Haisha no okurimono: Tokushu ian shisetsu RAA o meguru senryōshi no sokumen (Tokyo: Kōdansha, I985), I 7 .

${ }^{23}$ Yoshimi Yoshiaki, Comfort Women: Sexual Slavery in the Japanese Military During World War II (New York: Columbia University Press, 2000), I80; Yuki Tanaka, Japan's Comfort 
existed between the wartime and postwar prostitution systems, such as particular structural conditions of patriarchal power relations mainly embodied by the Japanese state functioning as pimp in the r94os, the stigmatization of the sex worker, and the continuity of sex trafficking networks that often forced young women into sexual slavery. ${ }^{24}$

However, prostitution as administrative practice in post-surrender Japan has to be more thoroughly historicized and draws attention to longer trajectories of patriarchal power in imperial Japan beyond the parallels to the wartime military prostitution system. ${ }^{25}$ Imperial Japan's governmentality, reverberating global entanglements of exchange and transfer in nation-, state- and empire-building, shaped prewar, wartime, and post-surrender prostitution. One regulatory technique, for example, was the police controlled prostitution license system with regular health inspections of sex workers. ${ }^{26}$ Imperial and colonial projects worldwide developed similar biopolitical strategies to regulate prostitution in order to administer gender roles, reproductive and nonreproductive sexualities, sexual encounters, and venereal disease. ${ }^{27}$ In most Asian, Latin American, and Western countries prostitution has been considered - although not uncontested-an important institution to secure social stability, control public health, and maintain gender roles and family ties since the nineteenth century and increasingly in the twentieth century. ${ }^{28}$ In colonial settings, some colonial administrations favored regulated prostitution to manage the

Women: Sexual Slavery and Prostitution during World War II and the US Occupation (London and New York: Routledge, 2002), i 66.

24 John Lie, "The State as Pimp: Prostitution and the Patriarchal State in Japan in the I940s," The Sociological Quarterly 38, no. 2 ( I 997): 26o; Fujime Yuki, Sei no rekishi gaku: kōshō seido, daitaiza taisei kara baishun bōshihō, yūsei hogohō taisei e (Tokyo: Fuji Shuppan, I997).

25 Sarah Kovner, Occupying Power: Sex Workers and Servicemen in Postwar Japan (Stanford, CA: Stanford University Press, 2012), I 4.

${ }^{26}$ Yutaka Fujino, Sei no kokka kanri: Baibaishun no kingen daishi (Tokyo: Fuji Shuppan, 200I); Yuki Fujime, "The Licensed Prostitution System and the Prostitution Abolition Movement in Modern Japan," positions 5, no. I (I997): I37-I42; Sheldon Garon, "The World's Oldest Debate? Prostitution and the State in Imperial Japan, I900-I945," American Historical Review 98, no. 3 (1993): 710-732.

27 Philippa Levine, "Introduction: Why Gender and Empire?," in Gender and Empire, ed. Philippa Levine (Oxford: Oxford University Press, 2004), I-I 3; Ann Laura Stoler, "Sexual Affronts and Racial Frontiers: European Identities and the Cultural Politics of Exclusion in Colonial Southeast Asia," Comparative Studies of Society and History 34, no. 3 (I992): 5I4-555.

28 Elizabeth J. Remick, Regulating Prostitution in China: Gender and Local Statebuilding, 1900-1937 (Stanford, CA: Stanford University Press, 2014); Donna J. Guy, Sex Eु Danger in Buenos Aires: Prostitution, Family and the Nation in Argentina (Lincoln, NE: University of Nebraska Press, I990); Judith R. Walkowitz, Prostitution and Victorian Society: Women, Class and the State (Cambridge: Cambridge University Press, 1980), 4; Mary Gibson, Prostitution and the State in Italy, I860-1915 (Columbus, OH: Ohio State University Press, I999), 
colonizers' sexuality and health, and also to maintain racial boundaries; the native sex worker did not only provide sexual services, but also served as an archetype of alleged non-white degradation to legitimate the need for colonial rule. ${ }^{29}$ Commercial sex itself was definitely not a new phenomenon. Yet, globally, newly implemented hygienic regulations and new modes of representing sex workers cast prostitution as a modern institution for administering a population's security, health, and morale, and it thus became a significant and signifying interface for sharing the experience of modernity. ${ }^{30}$

Japanese authorities appropriated, translated, and implemented modified imperial concepts of hygiene, sexuality, prostitution, and their regulation instantly after defeat. They re-formulated ideals of womanhood, domesticity, and racial purity to articulate Japanese sovereignty and national uniqueness through the post-surrender organization of prostitution. Thus, I want to suggest perceiving post-surrender Japan as a "liminal period," in which clearly fixed structures of power and meaning seemed to be destroyed, but could nonetheless be appropriated. ${ }^{31}$ The eventfulness of this short two-weeks period, establishing new rules of signification, was characterized by multiple discursive practices to produce meaning from the anxiety arising from Japan's defeat, surrender, and the imagining of the subsequent occupation. ${ }^{32}$

\section{At War's End: Rupture and Continuity of the "National Body"}

At the end of the war material and physical devastation exacerbated Japanese psychological despair severely affecting everyday life. Massive

I5-I6; Jessica R. Pliley, Policing Sexuality: The Mann Act and the Making of the FBI (Cambridge, MA: Harvard University Press, 2014), 5.

29 Philippa Levine, Prostitution, Race and Politics: Policing Venereal Disease in the British Empire (New York and London: Routledge, 2003), I 79; Ann Laura Stoler, "Making Empire Respectable: The Politics of Race and Sexual Morality in 2oth-Century Colonial Cultures," American Ethnologist I6, no. 4 (I989): 637.

30 Gail Hershatter, Dangerous Pleasures: Prostitution and Modernity in Twentieth-Century Shanghai (Berkeley, CA: University of California Press, 1997), 4; Alison Bashford, Imperial Hygiene: A Critical History of Colonialism, Nationalism and Public Health (New York: Palgrave Macmillan, 2004), 2.

31 Victor Turner, "Betwixt and Between: The Liminal Period in Rites of Passage," in Betwixt and Between: Patterns of Masculine and Feminine Initiation, ed. Louise Carus Mahdi, Steven Foster and Meredith Little (La Salle: Open Court, I987), 4-I9.

32 Thomas Rathmann, "Ereignisse Konstrukte Geschichten," in Ereignis: Konzeptionen eines Begriffs in Geschichte, Kunst und Literatur, ed. Thomas Rathmann (Köln, Weimar, Wien: Böhlau Verlag, 2003), IO-I 2, I 4; Jacques Derrida, "Signature Event Context," in Limited Inc (Evaston: Northwestern University Press, I988), I3. 
conventional bombing and the obliteration of Hiroshima and Nagasaki by atomic bombs had destroyed Japan's major cities. Mobilization for the war effort, military discipline, police surveillance, and food shortage all had created misery, suffering and hunger. News of significant civilian casualties from the fiercely fought Battle of Okinawa frightened many Japanese as to what might happen in the Japanese metropole (naichi) upon the enemy's arrival. ${ }^{33}$ The vague formulations of the Potsdam Declaration, issued on July 26, I945, stipulating the unconditional surrender of Japan, the loss of Japan's empire, and a military occupation by the Allied powers under the aegis of the Supreme Commander of Allied Powers and his headquarters (SCAP/GHQ) with the subsequent loss of Japan's sovereignty, reinforced Japanese uncertainty about the future. ${ }^{34}$

The threat of destruction represented by foreign occupation was also conveyed by Emperor Hirohito in his famous radio broadcast "Imperial Rescript on the Termination of the War" (Daitōa sensō shūketsu no shōsho) on August I5, I945. In the gyokuon-hōsō (literally translated as "Jewel Voice Broadcast") Hirohito officially announced the "end of the war" (shüsen) and Japan's acceptance of the Potsdam Declaration, without actually naming Japan's "surrender" or "defeat" (haisen). ${ }^{35} \mathrm{He}$ rather claimed:

The war situation has developed not necessarily to Japan's advantage, while the general trends of the world have all turned against her [Japan's] interest. Moreover, the enemy has begun to employ a new and most cruel bomb, the power of which to damage is, indeed, incalculable, taking the toll of many innocent lives. Should we continue to fight, not only would it result in an ultimate collapse and obliteration of the Japanese nation, but also it would lead to the total extinction of human civilization.

All his subjects, the "one hundred million people," would have to face hardships and sufferings, but, Hirohito continued, "it is according to the dictates of time and fate that We have resolved to pave the way for a grand peace for all generations to come by enduring the unendurable and suffering what is insufferable." The emperor thus called upon his subjects to "let the entire nation continue as one family from generation to

33 Awaya and Kawashima, "Haisen chokuzen no nihonjin no ishiki," in Haisenji, ro; Awaya, Gendaishi hakkutsu, 57. The Okinawa Prefectural Peace Memorial Museum counts more than I0०,000 civilian casualties. See: http://www.peace-museum.pref.okinawa.jp/ english/index.html (accessed March 24, 2017).

34 Takemae, Inside GHQ, 52-53.

35 Herbert Bix, Hirohito and the Making of Modern Japan (New York: Harper Collins, 2000), 529; Dower, Embracing Defeat, 36. 
generation, ever firm in its faith in the imperishability of its sacred land," and to unite the "total strength, to be devoted to construction of the future." All Japanese should "cultivate the ways of rectitude, foster nobility in spirit, and work with resolution-so that you may enhance the innate glory of the imperial state and keep pace with the progress of the world."36

Although Hirohito's speech addressed the future of Japan and encouraged the Japanese people to work hard to keep pace with world progress, the emperor's rhetoric was actually deeply reactionary. Hardly anyone in Japan fully understood the speech, radio commentators and journalists had to translate the emperor's words and explain their meaning in common Japanese in follow-up reporting. ${ }^{37}$ Moreover, Hirohito's terminology did not denounce imperial ideology, it was rooted in wartime and prewar propaganda that promoted the sacredness of the imperial institution, the divinity of Japan's soil, and the unity of the Japanese people-whereby the expression "one hundred million people" was a marker to encompass all subjects under imperial Japan's rule throughout Asia. ${ }^{38}$

Another pivotal ideological term that embraced all these features is kokutai, also uttered by Hirohito and which appeared in accompanying newspaper articles. Particularly the phrase kokutai goji, meaning the protection and preservation of the kokutai, expressed the desire to perpetuate Japan's unity at war's end..$^{39}$ Kokutai, usually translated into English as body politic or national body, is a vague and multi-faceted concept of modern Japanese nation-, state- and empire-building and a key reference for emperor-centered state ideology since the Meijiperiod (I868-I9I2). ${ }^{40}$ Its meaning somewhat oscillates between the German terms Staatskörper and Volksgemeinschaft and signifies the construct of a unity of the Japanese people, the Japanese state, its institutions and the Japanese emperor (tennō), which Iida Yumiko has called an "embodiment of a timeless Japanese cultural essence" in the process to define a modern Japanese national identity. ${ }^{41}$

36 "Imperial Rescript on the Termination of the War," August I4, I945, National Diet Library, Tokyo, http://www.ndl.go.jp/constitution/e/shiryo/or/or 7 shoshi.html (accessed April 20, 2013).

37 Dower, Embracing Defeat, 34.

38 Sharaly Orbaugh, Japanese Fiction of the Allied Occupation: Vision, Embodiment, Identity (Leiden: Brill, 2007), 2 I9-22 I.

39 "Sensō shūkyoku he seidan/taishō kanpatsusu," Yomiuri Hōchi, August I 5, I945.

40 Carol Gluck, Japan's Modern Myths: Ideology in the Late Meiji Period (New York: Columbia University Press, 1985), chapter V. On the multiplicity of kokutai's meanings, see Denis Gainty, Martial Arts and the Body Politic in Meiji Japan (New York: Routledge, 2013), 5-7.

41 Yumiko Iida, Rethinking Identity in Modern Japan: Nationalism as Aesthetics (New York and London: Routledge, 2002), 5. Earlier intellectual debates in the late Tokugawa-period 
Similar to many nation-building projects all over the world, one important institution for building and promoting the kokutai was the establishment of a modern health regime. All over the world, modern health regimes institutionalized in public health regulations and the clinic have been highly significant in nation-building projects. ${ }^{42}$ Japanese ideologues attempted to establish a sense of national belonging by integrating the individual body and its health into the "national body" which they conceived as an organic unity. ${ }^{43}$ The constitutive mechanisms of public health-as well as education-were particularly powerful in their entwinement with the construction of certain gender roles. Since the end of the nineteenth-century debates on public health and education included a strong emphasis on hygiene, domesticity, and reproduction with the ideal of the "wise mother and good housewife" (ryōsai kenbō). ${ }^{44}$ Women's roles became increasingly ascribed as being obedient to father and husband as well as to emperor and the state. ${ }^{45}$ Accordingly, the basic functions ascribed to women were to manage the household and educate children for the sake of creating loyal, obedient, and efficient imperial subjects, and the female body became a key symbol for the maintenance and continuity of the "national body." 46 Such ideals intensified in the r 930 and increasing militarization was accompanied by the repression of birth control, ban

(I603-I868) offered a vocabulary for Meiji-period ideologues to construct the kokutai and had already formulated the idea of unity and community. Susan Burns, Before the Nation: Kokugaku and the Imagining of Community in Early Modern Japan (Durham and London: Duke University Press, 2003), 6. See also: Harry Harootunian, Things Seen and Unseen: Discourse and Ideology in Tokugawa Nativism (Chicago: Chicago University Press, I988), 409.

42 Philip Sarasin, Reizbare Maschinen: Eine Geschichte des Körpers I 765-I9I 4 (Frankfurt/ M.: Suhrkamp, 200I); Ina Zweiniger-Bargielowska, Managing the Body: Beauty, Health, and Fitness in Britain, I880-1939 (Oxford: Oxford University Press, 2010).

43 Susan Burns, "Constructing the National Body: Public Health and the Nation in Nineteenth-Century Japan," in Nation Work: Asian Elites and National Identities, eds. Timothy Brook and Andre Schmid (Ann Arbor: University of Michigan Press, 2000), I 7-49; Sabine Frühstück, "Managing the Truth of Sex in Imperial Japan," Journal of Asian Studies 59, no. 2 (2000): 334; Gerald Figal, Civilization and Monsters: Spirits of Modernity in Meiji Japan (Durham, NC and London: Duke University Press, I999), 92-I04.

44 Shizuko Koyama, "The 'Good Wife and Wise Mother' Ideology in Post-World War I Japan," U.S.-Japan Women's Journal 7 ( I994): 47; Robert Smith, "Making Village Women into 'Good Wives and Wise Mothers' in Prewar Japan," Journal of Family History 8, no. I ( I 983): 70-84; Sharon H. Nolte and Sally Ann Hastings, "The Meiji State's Policy Towards Women, I890-1910," in Recreating Japanese Women, I600-1945, ed. Gail Bernstein (Berkeley, CA: University of California Press, I99I), I5I-I 74.

45 Vera Mackie, "Embodied Subjects: Feminism in Imperial Japan," in Japanese Women: Emerging from Subservience, I868-1945, eds. Hiroko Tomida and Gordon Daniels (Kent: Global Oriental, 2005), 97.

46 Kathleen S. Uno, "Death of 'Good Wife, Wise Mother'?," in Postwar Japan as History, ed. Andrew Gordon (Berkeley: California University Press, I993), 299-300. 
of abortions, and enforcement of eugenic laws; ultimately, the imperial state turned women more or less into breeding machines. ${ }^{47}$ Simultaneously, similar to most nationalistic constructions of gender, imperial Japan's authorities believed women to be the most vulnerable and endangered part of the nation. Especially during warfare, they construed the female body as open to violation and, to quote Ruth Seifert, conceived it "as always penetrable and endangered by rape." 48 For civil and military physicians, civil servants, politicians, public health officials, and educators female sexuality represented therefore always an ambivalence between security and danger, which had to be sincerely administered in order to secure the survival of the "national body."

However, until i945, kokutai evolved with Japan's imperial expansion in Asia. Japanese colonial administrations also employed the term as ideological slogan to encompass an imperial unity under Japanese leadership. The idea of a unified socio-political body was particularly explicit in colonial Korea, where colonial assimilation policies (dōka) attempted and propagated the integration of Korea and its people into Japan's imperial body politics under the catchphrase naissen ittai ("Korea and Japan as one body"). ${ }^{49}$ In Japan's colonies hygiene and public health were major vehicles to legitimize colonial rule under the supposedly benevolent and civilizing guidance of Japan, as has been the case in colonial India, among others. ${ }^{50}$ And although Japan's colonial administrations used hygiene and public health as constant markers for scaling Japan's empire and its people in order to create and maintain a hierarchy between an allegedly more modern Japan and the countries and people of Japan's empire, hygiene was heavily applied to integrate Japan's empire into Japan's body politics. ${ }^{51}$

47 Sabine Frühstück, Colonizing Sex: Sexology and Social Control in Modern Japan, (Berkeley, CA: University of California Press, 2003), I52-1 77; Jennifer Robertson, "Blood Talks: Eugenic Modernity and the Creation of New Japanese," History of Anthropology I 3 , no. 3 (2002): I9I-2I6.

48 Ruth Seifert, "Der weibliche Körper als Symbol und Zeichen: Geschlechtsspezifische Gewalt und die kulturelle Konstruktion des Krieges," in Gewalt im Krieg: Ausübungen, Erfahrungen und Verweigerung von Gewalt in Kriegen des 20. Jahrhunderts, ed. Andreas Gestrich (Münster: LIT Verlag, I996), 23.

${ }^{49}$ Choi, "The Discourse of Decolonization," 356; Bruce Cumings, Korea's Place in the Sun: A Modern History, updated edition (New York: W. W. Norton, 2005), i 76; Mark E. Caprio, Japanese Assimilation Policies in Colonial Korea, I910-1945 (Seattle, WA: University of Washington Press, 2009), I 53-I 70.

50 David Arnold, Colonizing the Body: State Medicine and Epidemic Disease in NineteenthCentury India (Berkeley: University of California Press, I993), 8.

51 Michael Shiyung Liu, Prescribing Colonization: The Role of Medical Practices and Policies in Japan-Ruled Taiwan, 1895-1945 (Ann Arbor, MI: Association for Asian Studies, 2009); 
Nevertheless, in the wake of defeat in August 1945, Japan's authorities apparently dropped the imperial baggage and the reference of kokutai must have changed. As is evident in the emperor's speech as well as in police reports and newspaper articles after defeat, they referred only to the people within the Japanese metropole (naiichi) as being supposedly endangered by the invading foreign soldiers, and they totally ignored the fate of formerly colonized people in Japan's empire. Within this web of meanings and references, kokutai goji, as pronounced by the emperor, had quite extensive and existential dimensions. Due to the notion of the kokutai as an organic body generated in close connection to public health, hygiene, gender, and sexuality, Japan's authorities viewed a military occupation subsequent to Japan's defeat as an intrusion of an alien other. They imagined the arrival of the occupation forces as a sexual "invasion" that would be inevitably accompanied by physical and sexual violence against Japanese women, and thus considered as a fundamental destructive threat to national unity.

\section{Conceptualizing the "Female Floodwall": Imperial Knowledge of} Prostitution

On August 18, 1945, the Police and Security Section of the Home Ministry sent a nationwide radiogram to all prefectural governors and police departments, most likely issued on behalf of the bureau's chief Hashimoto Masami. ${ }^{52}$ The radiogram ordered police units to set up comfort facilities (ian shisetsu) all over Japan to protect Japanese citizens. These facilities, which included bars, restaurants, cabarets, and brothels, were to be located in designated areas, which were considered off-limits to Japanese civilians. It was the duty of the police to patrol these areas and to monitor all facilities. Furthermore, local police units were instructed to supervise and actively support the establishment of all facilities, and to oversee the recruitment of entertainers, dancers, barmaids, and licensed as well as unlicensed prostitutes. ${ }^{53}$

\footnotetext{
Todd A. Henry, "Sanitizing Empire: Japanese Articulations of Korean Otherness and Construction of Early Colonial Seoul, I905-19 1 9," Journal of Asian Studies 64, no. 3 (2005): 639-675; Judith Farquhar and Marta Eileen Hanson, eds., "Empires of Hygiene," Special Issue, positions 6, no. 3 (I998).

52 Yoshimi, Comfort Women, i8o.

${ }^{53}$ Naimushō Keihokyokuchō, "Gaikokugun chūtonchi ni okeru ian shisetsu ni tsuite," in Baishun ni kansuru shiryō, ed. Rōdō Shō Fujin Shōnen Kyoku (Tokyo: Rōdō Shō, I 955), I $2-13$.
} 
In Japan, the concept of regulated prostitution in its modern form, defined by police security and public health regulations, was first introduced in Nagasaki around I 860 after the encounter with foreign sailors. ${ }^{54}$ The Japanese state installed a licensed prostitution system along French and German regulation models. In order to limit the spread of venereal diseases as well as social and moral vices, prostitution was only allowed in designated areas with licensed brothels and venereal disease clinics patrolled by the police. ${ }^{55}$ First inaugurated in I876, a nationwide regulation compelled sex workers to undergo regular medical examinations that were compulsory to receive a license issued by local police units, a procedure focusing on the protection of male clients rather than on the health of the sex workers. Ever since, the licensed prostitution system received significant attention in Japan's modern health regime, in which the body of the sex worker was incorporated into Japan's modern health, education, and military institutions, and helped to substantiate the normalization processes of creating a modern and pure Japanese body. ${ }^{56}$

In the Japanese metropole there was a strong influence of nongovernmental sexologists and moral reformers campaigning against the state-sanctioned license system, questioning state authority on matters of sexuality and criticizing the state for sponsoring extra-marital sex. Yet most of these individuals and groups were integrated into governmental programs of public health and morality that ultimately enabled the Japanese state even stronger interventions into society. State intervention in the regulation of hygiene and sexuality rapidly intensified during the I920s and I930s, and the regulation of prostitution allowed agents of the state to control hygiene and sexual morals and even to define reproduction, domesticity and gender roles. ${ }^{57}$ Hence, prostitution became an integral part of the modern health and education regime since the Meiji period, which was stigmatized as "dishonorable trade" ( $\operatorname{sh} \bar{u} g y \bar{o})$ and functioned as a reference ex negativo to the ideal of the "wise mother and good housewife" to define middleclass domesticity. ${ }^{58}$

In practice, however, Japan's authorities considered and maintained prostitution as a necessary institution to control the male sex drive and

\footnotetext{
54 Susan Burns, "Bodies and Borders: Syphilis, Prostitution, and the Nation in Japan, I860-1890," U.S.-Japan Women's Journal (English Supplement), no. I5 (I998): 3-30; Frühstück, Colonizing Sex, 42.

55 Fujime, "The Licensed Prostitution System," I37-I 42.

${ }^{56}$ Frühstück, Colonizing Sex, 42-48, I05.

57 Garon, "The World's Oldest Debate."

58 Fujime, "The Licensed Prostitution System," I 40.
} 
to guarantee healthy and secured sex for men, which would supposedly prevent daughters of respectable families from depravity and protect the family in general as haven of disease-free reproduction. ${ }^{59}$ Feminists worldwide criticized the double standard in such concepts of prostitution, because it demanded women to be chaste while allowing men to have extra-marital sex. ${ }^{60}$ Nonetheless, Japanese military and public health officials were particularly keen regulating the health of the male body that signified, predominantly in form of the manly soldier, the security and expansion of imperial Japan. Since the meaning of the male body was generated in the symbolic entwinement with nation, empire and war, sick soldiers, and especially those infected with venereal disease, were signs of disciplinary and moral weakness and perceived as danger to national security-tightly regulated prostitution was supposed to limit such risks. ${ }^{61}$ Licensed lower-class sex workers thus functioned to channel undisciplined male sexual desire to protect middle- and upper-class women and to secure healthy and "proper" reproduction. ${ }^{62}$

This modern form of prostitution was not limited to Japan proper, but developed in Japan's world history relations. During the second half of the nineteenth-century, many poor Japanese women emigrated or were forcefully recruited as sex workers all over East and Southeast Asia, settled in port cities such as Shanghai, Hong Kong and Singapore, and became an integral part of imperial Japan's transnational economy. ${ }^{63}$ With Japan's imperial expansion, the Japanese government became increasingly concerned about the empire's reputation due to the magnitude of Japanese sex workers overseas and tried to regulate the transnational sex trade. ${ }^{64}$ They introduced a license system in Taiwan, Korea and China to administer prostitution and the growing Japanese population in Japan's colonies

\footnotetext{
${ }^{59}$ Garon, "The World's Oldest Debate?," $72 \mathrm{r}$. Indeed, this is a world historical debate: Alain Corbin, Women for Hire: Prostitution and Sexuality in France after 1850 (Cambridge, MA: Harvard University Press, 1990), 3-29; Ruth Rosen, The Lost Sisterhood: Prostitution in America, 1900-1918 (Baltimore, MD: Johns Hopkins University Press, I982), 6.

60 Rosemarie Tong, Women, Sex, and the Law (Lanham, MD: Rowman\&Littlefield, I984), 48 .

${ }^{61}$ Frühstück, Colonizing Sex, 28.

62 Garon, "The World's Oldest Debate?," 719-720, 729-730.

${ }^{63}$ Bill Mihalopulos, Sex in Japan's Globalization, 1870-1930: Prostitutes, Emigration and Nation-Building (London: Pickering \& Chatto, 20 I I ), I-I I; Hershatter, Dangerous Pleasures; Philip Howell, "Race, space and the regulation of prostitution in Colonial Hong Kong," Urban History 3I (2004): 229-248; James Francis Warren, Ah Ku and Karayuki-san: Prostitution in Singapore, I870-1940 (Oxford: Oxford University Press, I993), 32.

64 Harald Fischer-Tiné, Low and Licentious Europeans: Race, Class and 'White Subalternity' in India (New Delhi: Orient Blackswan, 2009), I86-232.
} 
and Japanese overseas settlements. ${ }^{65}$ During the I93os, measures to control prostitution further intensified: Japanese military officers and bureaucrats organized a system of military prostitution and forced women, predominantly from Japan's colonies, into sexual slavery in brothels in garrison towns and along the front lines. ${ }^{66}$ Yet, comfort stations (ianjo) were also erected within the Japanese metropole. In the wartime period, when extra-marital social and sexual relations between men and women in general were increasingly controlled, ${ }^{67}$ Japanese authorities established ianjo near military bases and armament industrial centers as part of wartime mobilization. ${ }^{68}$ Such measures enforced the meaning of prostitution as heteronormative institution for social hygienic regulation, which Japan's authorities deliberately applied to preserve public peace (chian) and morality ( $f \bar{u} z o k u)$, to channel male sexual desire, to protect female middle- and upper-class sexuality and foster biological reproduction with the aim to preserve the continuity of the Japanese "national body." As the Home Ministry's directive shows, it was the same logic underlying the decision by Japan's authorities to establish comfort stations for the occupiers at the end of World War II.

The desire for nationalist preservation and even essentialization in the program to provide sexual outlets for the occupiers after the war is most apparent in the founding of the Tokushu ianshisestu kyōkai around August 20, I945, commonly known under the later name Recreation and Amusement Association (RAA). The RAA, initiated by Japanese politicians and granted police support as well as financial aid, was a semi-governmental association to organize brothels and other recreational facilities for the occupation forces. ${ }^{69}$ The zeal for a nationalist postwar order of the RAA is documented in the inaugural speech of Miyazawa Hamajirō, the president of Tokyo's gastronomy association and director of the RAA, held on August 28, I945, in front

65 Youn-ok Song, "Japanese Colonial Rule and State-Managed Prostitution: Korea's Licensed Prostitutes," positions 5, no. I ( I997): I 7I-2 I9; John Lie, "The Transformation of Sexual Work in 2oth-Century Korea," Gender EF Society 9, no. 3 (I 995): 3 I 3 ; Taylor Atkins, Primitive Selves: Koreana in the Japanese Colonial Gaze, I9 IO-45 (Berkeley, CA: University of California Press, 20ıо), I47-ı 86; Sō Fujinaga, "Shokuminchi kōshō seido to nihongun 'ianfu' seido," in Shokuminchi to sensō sekinin, ed. Noriyo Hayakawa (Tokyo: Yoshikawa Kōbunkan, 2005), 9.

66 John Lie, "The State as Pimp," 257; Yoshimi, Comfort Women.

67 David Ambarras, "Juvenile Delinquency and the National Defense State: Policing Young Workers in Wartime Japan, I937-1945," Journal of Asian Studies 63, no. I (2004): 34, 4I; Garon, "The World's Oldest Debate?," 728.

${ }^{6}$ Fujino, Sei no kokka kanri, I43-144.

69 Duus, Haisha no okurimono, 30; Tanaka, Japan's Comfort Women, I4 I. 
of the Imperial Palace in Tokyo. August 15, 1945, according to Miyazawa, marks the end of an era:

At this time, we are imposed ... with the difficult task to comfort the occupation forces as part of the urgent national facilities for postwar management. . . [T]hrough the human sacrifice of several thousand 'Okichis of the Shōwa period' we build a floodwall against the raging waves, helping to defend and nurture the purity of our race, thereby becoming an invisible base for the postwar social order. ${ }^{70}$

Okichi is the name of a geisha, who is said to have been commanded by the Tokugawa shogunate (bakufu) to serve the first U.S. general consul Townsend Harris in the I85os during his residency in Japan, before she committed suicide. It is believed that her explicit sexual services contributed highly to the peaceful negotiations for diplomatic relations between Japan and the United States. The legend of Okichi, embedded into Miyazawa's speech of progress and modernity, therefore constructed a similar and supposedly inevitable sacrifice to be made for the well-being of the nation in the postwar period. The speech itself was closed with banzai-cheers to salute the emperor and later released as an "oath" by the RAA in the defense of the kokutai to preserve the "3,000 years of unchanging lineage of the emperor and the Japanese people." $" 1$

Following the construction of the vulnerable female body and sex workers' lower-class based position to secure the kokutai, Miyazawa postulated the defense and nurture of the "purity" of the Japanese race (minzoku) in his inaugural speech and thus linked post-surrender prostitution closely to notions of racial hygiene during the prewar and wartime period. ${ }^{72}$ According to the historian Awaya Kentarō, the fear of racial contamination through rape of Japanese women by U.S. servicemen determined the idea to set up brothels for the occupation forces. Among others, Awaya has mainly referred to Konoe Fumimaro, also conspicuous for being the founder of the para-fascist organization Taisei yokusankai (Imperial Rule Assistance Association) and threetime Prime Minister of Japan. Konoe was apparently arguing for the establishment of a prostitution scheme to prevent the rape of Japanese women and thereby to save Japan's "purity of blood" (junketsu). ${ }^{73}$

\footnotetext{
${ }^{70}$ RAA, "Tokushu ianshisestu kyōkai seimeisho," in Nihon fujin mondai shiryō shūsei, Vol. I, ed. Fusae Ichikawa (Tokyo: Domesu Shuppan, I978), 536-537.

${ }^{71}$ RAA, "Tokushu ianshisestu kyōkai seimeisho," 535.

72 Frühstück, Colonizing Sex, I53.

73 Awaya, Gendaishi hakkutsu, 69. See also Samon Kinkabara and Eiji Takemae, Showashi: kokumin no naka no haran to gekido no hanseiki (Tokyo: Yūhikaku, I989), 244.
} 
Racist thinking was not uncommon among various fascist and ultranationalist organizations, and certainly surfaced in Japan's often violent colonial rule in Taiwan, Korea and China. ${ }^{74}$ Nevertheless, official statements as well as eugenic legislation and even wartime propaganda did not promote the racial superiority of Japan in a biologically determined sense. ${ }^{75}$ The Japanese empire and the Japanese nation itself were in fact commonly perceived as being multi-racial, while Japanese imperial ideologues struggled with the double bind of Japan's equal position among other imperial powers, its imperial superiority in the colonies and the simultaneous legitimation of Japan as benevolent Asian leader of Asia and the inclusion of other Asian people within the Japanese empire. ${ }^{76}$ As Oguma Eiji has argued, the idea of the Japanese self was quite inclusive, which intellectual movements such as Pan-Asianism imply, whereby the concept of being Japanese always shifted with the political environment. ${ }^{77}$ Racial hygiene in the Japanese metropole (naiichi) was thus rather focused on the creation and reproduction of healthy and disciplined subjects of the empire. Such notion also translated into the most aggressive agent of Japan's imperial expansion, the Imperial Japanese Army, who wasdespite various racially motivated killings by Japanese soldiersnonetheless highly interested in the integration of soldiers from Japan's colonies such as Korea and Taiwan. ${ }^{78}$ While this surely meant to legitimate Japan's imperialistic expansion and to ground Japan's hegemony throughout Asia, multi-racial inclusion signaled also a desired autonomy in constant negotiation with the imaginary omnipresent "West" as a reference for civilization and modernity. ${ }^{79}$

\footnotetext{
${ }^{74}$ Michael Robinson and Gi-wook Shin, "Introduction: Rethinking Colonial Korea," in Colonial Modernity in Korea, eds. Gi-wook Shin and Michael E. Robinson (Cambridge, MA: Harvard University Press, 1999), 7-8.

75 Hyung Il Pai, Constructing "Korean" Origins: A Critical Review of Archeology, Historiography, and Racial Myth in Korean State-Formation Theories (Cambridge, MA: Harvard University Press, 2000), 35-4I; Robertson, "Blood Talks," I97.

76 Nadin Heé, Koloniales Wissen und koloniale Gewalt: Japans Herrschaft in Taiwan 1895-1945 (Frankfurt/M.: Campus, 2012), 29-35.

77 Eiji Oguma, Tan'itsu minzoku shinwa no kigen: Nihonjin no jigazo no keifu (Tokyo: Shinyōsha, I995), 395. See also: Sven Saaler, "Pan-Asianism in Modern Japanese History: Overcoming the Nation, Creating a Region, Forging an Empire," in Pan-Asianism in Modern Japanese History: Colonialism, Regionalism and Borders, eds. Sven Saaler and J. Victor Koschmann (New York: Routledge, 2007), I-I 8; Sven Saaler and Cristopher W. A. Szpilman, "Introduction: The Emergence of Pan-Asianism as an Ideal of Asian Identity and Solidarity, I 850-2008," in Pan-Asianism: A Documentary History, Volume 2: 1920-Present, eds. Sven Saaler and Cristopher W. A. Szpilman (Lanham, MD: Rowman\&Littlefield, 20 I I), го.

${ }^{78}$ Fujitani, Race for Empire, I I; Heé, Koloniales Wissen und koloniale Gewalt, 2 I 8.

${ }^{79}$ Naoki Sakai, "'You Asians': On the Historical Role of the West and Asia Binary," The South Atlantic Quarterly 99, no. 4 (2000): 792-793. Japanese wartime thinkers applied this
} 
Against this backdrop, racial hygienic programs and racial scaling in the prewar and wartime period functioned much more as an expression of cultural maturity than as biological determined racial superiority ${ }^{80}$

Nonetheless, considering Miyazawa's speech in front of the imperial palace and the fear of the Japanese emperor, politicians, bureaucrats, policemen, journalists, and entrepreneurs that the occupation forces will inevitably mass rape Japanese women and thereby contaminate and destroy the kokutai, the conceptualization of prostitution as administrative practice obviously contained a certain racist and culturalist thought. The vocabulary to formulate such ideas was provided by prewar and wartime discourses of race, gender, class, and sexuality, which could be appropriated and adapted in the immediate postwar period. The reinterpreted ideals and concepts of the kokutai with the image of the chaste female body ultimately satisfied a specific nationalistic desire to imagine a post-surrender "Japaneseness." The conceptualization of prostitution to comfort the occupiers thus served not only the purpose to meet the supposed sexual lust of the occupying army's soldiers and sailors, but simultaneously to comfort the soon-tobe occupied as well.

\section{Organizing Prostitution in Post-Surrender Japan: Agents and PRACTICES}

Nationalistic ideals and desires based on gendered and racialized concepts of sexuality generated in imperial Japan were also palpable in the recruitment of women to work in the postwar brothels, bars, beerhalls, restaurants, and cabarets. John Lie has provocatively suggested labeling the Japanese state as pimp, whose agents and institutions would have been mainly responsible for organization and recruitment of prostitution throughout Japan's empire in (military) comfort stations during the war as well as domestically within Japan after defeat in I $945 .{ }^{81}$ Although I do not intend to neglect the involvement and responsibility of Japan's authorities in that matter, Lie's assessment seems vague and undermines the complexity of organizing sex work and recruiting sex workers in the immediate post-surrender period. Of

\footnotetext{
logic in the very attempt to overcome the "modern West." Harry D. Harootunian, Overcome by Modernity: History, Culture, and Community in Interwar Japan (Princeton, NJ and Oxford: Princeton University Press, 2000).

80 John W. Dower, War without Mercy: Race and Power in the Pacific War (New York: Pantheon Books, I986), 265.

${ }^{81}$ Lie, "The State as Pimp," 25 I.
} 
course, the Home Ministry released an ordinance to Japan's national police force to set up recreational facilities and to recruit women, probably pushed by governmental officials and politicians. Local police units were occasionally directly responsible in carrying out that order. In addition, however, a variety of agents and groups of actors such as entrepreneurs of the entertainment business, labor brokers as well as ultranationalist and fascist groups were heavily involved and contributed to the efforts to establish the "female floodwall." Although most of them were somehow linked to Japan's imperial state, the recruitment itself was not singularly planned and executed by a central governmental agency. Nevertheless, Japan's authorities were highly supportive to those mostly private and semi-governmental groups and organizations, and helped them financially and encouraged them politically to implement a recreational scheme. Obviously, Japan's empire had not vanished overnight, and neither had Japan's imperial agents, of whom some were eager to provide sexual outlets for the occupiers.

The tight collaboration between officials of Japan's imperial state and private agents of the sex industry is documented for a former amusement and brothel quarter in Yokosuka, a major port for the Imperial Japanese Navy in the south of Kanagawa prefecture. Close to the port facilities, a number of privately run brothels were maintained to cater to Japanese sailors when allowed ashore, which apparently became a highly lucrative business for Yokosuka's licensed sex workers during the wartime period. On August 29, I945, a policeman and a representative of the Home Ministry came to one of Yokosuka's brothels and asked the landlord to gather all sex workers. In a short speech the women were told:

From tomorrow you must partner with the Americans. This is an order coming from the Gods (okami kara no meirei), and we all carefully follow them. It is your sacrifice (gisei) that will make it possible for Japan's women to escape the fangs of American soldiers. Although this is truly painful for you, in the Gods' great will, for the country, and for the dignified imperial family's princesses, we urge you to shed your tears. The destiny of all Japanese women is the burden upon your shoulders. ${ }^{82}$

Following the speech, the women went to their rooms to burn all pictures of Japanese warships and sailors, and the brothel owner posted

82 Tsutomu Itsushima, Kuroi Haru: Beigun, Panpan, onnatachi no sengo, 2nd ed. (Tokyo: Tōgosha, I985), 28-29. 
a sign saying "Welcome, U.S. soldier" at the brothel's door to greet the new customers. ${ }^{83}$ The remnants of Japan's empire were thus twofold: imperial ideology legitimated the enterprise and imperial Japan's license system's institutions and labor was remodeled for the deliberate use in the post-surrender period to cater to the occupiers.

Various prefectural police departments also engaged in the recruitment of sex workers instantly in August i945. Units of the Kanagawa Prefectural Police Department, for instance, started to gather formerly or still licensed prostitutes and inspected various locations if suitable as brothels, bars and dance halls in the Yokohama area. Subsequently, an apartment building in Yamashita-chō in Yokohama's Naka Ward was chosen and opened under the name Goraku-sō on August 28. ${ }^{84}$ In most cases, however, the police usually supervised the recruitment of women and provided logistics. They could rely on the police's filing cabinet, in which registered sex workers' names, addresses, personal descriptions with photographs and license records were meticulously archived, as a most efficient tool to personally approach women for recruitment. ${ }^{85}$ Another advantage for the police's recruitment campaigns and support was access to stored food and other consumer goods such as clothing and blankets, which were strictly rationed during the war years. Additionally, the police gathered commodities like alcohol, but also sanitary products, futons and other furniture. They attempted to convert factories and factory dormitories that endured Allied bombardment into brothels and beer halls, and used police trucks for transportation to furnish the facilities. ${ }^{86}$

On other occasions, the police depended on privately operating labor brokers, who could themselves rely on their decades old sex trafficking networks. Labor brokers usually maneuvered within legal limbo, because, as Fujime Yuki has argued, imperial Japan's prostitution regulation "created a loophole through which such trafficking was permitted if based on free will." 87 Such supposed freedom to choose sex work as a means of living, however, was often coerced through debt dependency. After concluding a contract with brokers and brothel

83 Itsushima, Kuroi Haru, 29.

84 Inoue, Senryōgun ianjo, 57.

85 Kikan Sensō Sekinin Kenkyū, ed., Nippon keisatsu no 'ianfu' seisaku, Vol. I3 (Tokyo: Keishichōshi hensan iinkai, I996), 53; Allan Sekula, "Der Körper und das Archiv," in Diskurse der Fotografie: Fotokritik am Ende des fotografischen Zeitalters, Vol. 2, ed. Herta Wolf (Frankfurt/M.: Suhrkamp, 2003), 286.

86 Tanaka, Japan's Comfort Women, I35.

87 Fujime, "The Licensed Prostitution System," I 40. 
owners, poor young women or their families received advanced payment which had to be redeemed through the girls' labor-a system sustaining "the hypocrisy that the state's recognition of prostitution demonstrated its sympathy for the plight of the poor." 88 Sex trafficking networks existed throughout Japan and particularly poor regions in the countryside functioned as reservoir for traffickers to gather young women and bring them to licensed brothels in Japan's major cities, and across the Japanese empire. ${ }^{89}$ Although it is hard to prove, it is nevertheless highly conceivable that such networks were still active or were reactivated in the post-surrender period. Evidence is, however, that the police issued special travel documents to labor brokers allowing them to travel to the countryside where many women and children had fled to in order to find food, escape Japan's bombed cities or hide from the arriving occupiers. The idea was to offer food, clothing and shelter, if women were willing to join and work in the newly established entertainment centers. ${ }^{90}$

The police and labor brokers were not the only agents involved in the recruitment of women as sex workers, barmaids, and dancers. As Yoshimi Yoshiaki has shown, right-wing politicians and fascist organizations contributed to establish prostitution for the occupiers. ${ }^{91}$ Sasagawa Ryōzō, the younger brother of Greater Japan National Essence League's president Sasagawa Ryōichi, apparently opened together with fellow members of the Dai Nippon Kokusui-league the "American Club" in Osaka on September 18, 1945. ${ }^{92}$ And also Hishitani Toshio, the leader of the Greater Japan Sincerity Association (Dai Nippon Sekisei-kai) in Iwate Prefecture, a youth organization fashioned similar to the Hitler Youth in Nazi Germany, was apparently taking active part in organizing sex work for the occupiers. A report by the prefectural governor's office stated that Hishitani "involved himself with the people establishing comfort facilities for accommodating the Allied forces currently occupying the area." ${ }^{93}$ Although it is difficult to prove the cooperation between fascist organizations, yakuza-gangs and local police units, it was well known by Japan's authorities who engaged in the project to provide sex for the occupiers.

\footnotetext{
${ }^{88}$ Fujime, "The Licensed Prostitution System," I4I.

89 Mihalopulos, Sex in Japan's Globalization, 25-27.

90 Kanagawa-ken keisatsu-shi hensan iinkai, ed., Kanagawa-ken keisatsu-shi (Yokohama:

Kanagawa-ken keisatsu honbu, 1974), 355-360.

91 Yoshimi, Comfort Women, I82.

92 Awaya and Kawashima, eds., Haisenji, Vol. 6, I 22-123.

93 Awaya and Kawashima, eds., Haisenji, Vol. 2, 96.
} 
The most conspicuous organization in the recruitment of women was the RAA. The RAA received generous funding by the Ministry of Finance (zaimushō) through an instant low-interest credit over 30 million yen from the Nippon Kangyō Bank in September i945. Ikeda Hayatato, who was at the time the director of the ministry's tax division and became elected prime minister of Japan between I960 and I964, apparently negotiated the credit. ${ }^{94}$ Local police and military units granted access to rationed commodities such as blankets, beds and toiletries, and also shared their prostitution license files to help recruitment. ${ }^{95}$ The RAA had thus enough resources to rent or buy facilities, furnish its establishments, offer food and salaries, and to run public recruitment campaigns. Advertisements were expansively spread through various channels. In newspapers, the RAA solicited so called "special girls" who would receive good and advanced payment, food and shelter, and travel expenses for applicants from the countryside. ${ }^{96}$ The RAA also addressed young women on posters. One prominent exemplar hung in front of the RAA's main office in the old Mitsukoshi department store on the Ginza, a major street and district in Tokyo:

Announcement to the New Japanese Woman [shin nihon josei]. For the postwar management [sengo shori] in the situation of national emergency [kokka tekina kinkyüshisetsu], we require the initial cooperation [sossen kyōroku] of the new Japanese woman to participate in the great project to comfort [ian] the occupation forces. Female employees between $\mathrm{I} 8$ and 25 years old are wanted. Accommodation, clothes and meals will be provided. ${ }^{97}$

The fact that Ginza was the epicenter of such publicity bares a certain irony of history: Ginza was a major site where the discourse of "modern life" with its trope of the "modern girl" (moga)—a figure emerging worldwide-manifested itself in the I920s and I930s, produced in mass media, modern architecture and practices of consumption. ${ }^{98}$ At the

\footnotetext{
94 Duus, Haisha no okurimono, 43-45; Inoue, Senryōgun ianjo, I 7.

95 Kikan Sensō Sekinin Kenkyū, ed., Nippon keisatsu no 'ianfu' seisaku, Vol. I 3, 53.

96 "Tokushu ian sbetsu onago jūgyōin boshū," Yomiuri Hōchi and Mainichi Shimbun, August 29 and 30, I945.

${ }_{97}$ A transcript of the poster is provided by Ichikawa, ed., Nihon fujin mondai shiryō shūsei, Vol. I, 537 .

98 Harootunian, Overcome by Modernity, I3; On the "modern girl" as global phenomenon, see: Aly Eve Weinbaum et al., eds., The Modern Girl Around the World: Consumption, Modernity, and Globalization (Durham, NC and London: Duke University Press, 2008).
} 
end of the war, Ginza as the rest of Tokyo was destroyed by Allied bombings and could not encode the devastation and misery of the war with the phantasies of modern life. And also the trope of the "New Japanese Woman," a euphemism recapitulating the propagated but never achieved emancipation of women that already signified the tragedy of modern life decades ago and only repeated itself as farce in 1945, could never be truly accessed in the ruins of the Ginza. The young women of Japan's lowest classes between $\mathrm{r} 8$ and 25 years old were recruited in their material need of food, clothing and accommodation. In addition they were incorporated into a nationalist, patriarchal, heteronormative project, which was meant to signal the erection of a new Japan. Yet, as it was the case in imperial Japan, women of lower-class and/or colonial background continued to function - again - in their role as prostitutes as a protective zone to regulate Japan's sexualities and channel male sexual desire to protect "respectable" reproductive sexuality-and to absorb Japan's authorities fear of emasculation. ${ }^{99}$

To what extent the recruitment campaigns were actually fruitful is impossible to measure and there are hardly any records of responses to newspaper ads or the RAA's recruitment posters. Kobayashi Daijirō and Murase Akira have offered a rare story in which a woman still dressed in her wartime work suit monpe entered the RAA office, curious about the advertised job. She was told she would receive a dormitory place, clothes, food, and salary for her efforts to comfort (ian) soldiers, notably as a dancer, and that she would be working for her country and the Japanese people. The women was apparently not instantly attracted to that kind of work and seemed puzzled by the scope of what a dancer had to perform in a comfort facility (ianjo). In the end, however, she was persuaded to take the job, drawn into it by the prospect of food, shelter, and money. ${ }^{100}$ The decision to accept the RAA's job offers was thus forced upon those women by socio-economically catastrophic circumstances-misery, hunger, and despair-which the RAA deliberately exploited in Japan's post-surrender sex work scene.

On other occasions, women were recruited by systematic coercion or even brutal force (or the threat of violence). Coerced debt is but one legacy of Japan's imperial past in Iwahashi Tomiko's biography, whose life story as postwar sex worker literarily rooted in imperial Japan's history. Tomiko was born in Tokushima on Shikoku in I929, but moved

${ }^{99}$ Michael Molasky, The American Occupation of Japan and Okinawa: Literature and Memory (New York: Routledge, I999), I05.

100 Kobayashi Daijirō and Murase Akira, Minna wa shiranai kokka baishun meirei, New Edition (Tokyo: Yūzankaku Shuppan, I992), 24-25. 
to Japanese occupied territories in Southern China. In January I946, then seventeen-year old Tomiko repatriated together with her family from Guangzhou in southern China back to Japan. Around September the same year, after all her relatives had passed away and she had no place to stay, Tomiko decided to leave Shikoku and find work in Osaka. As she arrived at Osaka station, a forty years old man approached her and offered her a maid's job at a place called Santō. Without further second thoughts Tomiko instantly took the job and moved into the Santō House. By December, Tomiko realized that most women working at the house sometimes "took clients" (kyaku o toru), usually servicemen of the occupation forces. Around the same time, the man who offered her the maid's job told her that she already owed the Santō House over 2,000 yen for expenses since she moved into the place, and that it would be useless to quit or run away. Thus, Tomiko saw no other option to "take in clients" herself in order to pay off her debts and to hope for a better future living. ${ }^{101}$

Physical violence in form of kidnapping and rape was also used to recruit women. According to a rape victim's testimony, a group of young women mobilized during the war in the Women's Youth Corps (joshi seinendan) had worked at an armament factory near Kure, Hiroshima prefecture. They became war orphans due to the atomic bombing and kept on staying at the factory's dormitory. On September I4, I945, a Japanese male, Yoneyama Genjirō, who identified himself as the Executive Secretary of the Association for the Maintenance of Public Order in the Chūgoku Region assigned by the Home Ministry (naimushō shitei/chianijikai chūgoko chihō kanji), came by the factory in an army truck. After he handed food and cigarettes from occupation forces supplies to the factory manager, he addressed nine of the women telling them that he came all the way from Osaka to seek the help of "ideal Japanese women" to "protect the chastity of Japanese women from the evil influence of the occupation army," which he claimed would be a task of "divine will" (shini). Yoneyama put the scared women into the truck, and brought them after a long ride to two different places where the women were gang-raped each time by a different group of foreign soldiers. Subsequently, a medical officer examined them on venereal disease, before Yoneyama brought the women to a comfort facility (ianjo). ${ }^{102}$ As has been discussed above, pushing young women into

101 Tomiko Iwahashi, "Gaishō no shuki," in Nihon fujin mondai shiryō shūsei, Vol. I, ed. Ichikawa, 568-569.

102 Tsutomu Itsushima, Kuroi Haru: Beigun, Panpan, onnatachi no sengo, 2nd ed. (Tokyo: Tōgosha, I985), 30-36. 
debt dependency and maintaining sex-trafficking networks with the use of brutal force have a longer trajectory in imperial Japan's modern history of prostitution. The tragic episodes of Tomiko and the group of factory workers demonstrate that such trajectories reverberated into post-surrender Japan and highlight Japanese men's complicity in acts of sexual violence against Japanese women at the end of the war. In particular, it underscores the class-based exploitation of some women in order to protect middle- and upper-class women's sexualities, and satisfy male sexual, economic and political desires.

\section{CONCLUSION}

Upon arrival of the occupation forces, occupation army servicemen patronized the recreational facilities in large numbers. In 1946, however, U.S. occupation authorities abolished Japan's licensed prostitution system with the main aim to limit high rates of venereal disease and to prohibit sex-trafficking. Obviously, sex work did not vanish, and continued in privately run brothels, cabarets and bars, or as decentralized street prostitution in parks, railway underpasses, and nearby occupation army camps. The first national law in Japan to abolish sex work passed the Diet in May 1956, four years after the occupation of Japan. ${ }^{103}$ Japan's authorities efforts to initiate the "female floodwall," however, had significant future impact on imagining a postwar Japan.

As has been (and still is) the case all over the world, forces of global modernity structured sexual identities and practices to support militant imperialism as well as defensive nationalism in many emerging states. ${ }^{104}$ Japan's experience at the end of World War II was thus historic specific yet not singular. During the two weeks between Japan's surrender and the arrival of the occupation forces a new understanding of a Japan and Japanese belonging seemed to have emerged. The nationalistic imagination rose out of the fantasized confrontation with the arrival of the occupation forces as an intimidating other-indeed a product of transnational entanglement. The fictionalized fear of raping and looting soldiers and sailors of the occupation forces fueled the idea

\footnotetext{
${ }^{103}$ Kovner, Occupying Power, 138.

104 Tony Ballantyne and Antoinette Burton, "Introduction: Bodies, Empires, and World Histories," in Bodies in Contact: Rethinking Colonial Encounters in World History, eds. Tony Ballantine and Antoinette Burton (Durham and London: Duke University Press, 2005), $4-5$.
} 
of erecting a "female floodwall" to prevent an alleged sexual invasion targeting Japanese women. At this very moment, haunted by defeat, male agents of the Japanese imperial state and the sex industry reformulated the contours of the "national body" and its apparent core-Japan's purity, embodied by the chaste Japanese woman-in order to secure a newly imagined "Japaneseness." The imagined terrifying presence of the occupiers catalyzed Japanese identification practices with the wish for cultural and racial autonomy versus the occupiers, and discursive patterns prevalent in imperial Japan echoed back, were appropriated and re-narrated to fill the referenceless gap of the traumatic experience of defeat. ${ }^{105}$ Certain notions of sexuality, gender, race and class, which had been deeply inscribed into imperial Japan's health, education and licensed prostitution system-and which in turn have been the outcome of Japan's global interaction with health, education and police systems worldwide-, affected the postsurrender desire for a decided Japanese identity and provided the language to articulate it. It seems conspicuous - in addition to what Leo Ching has called Japan's "lack of decolonization" in absolving the emperor from war responsibility, denying Japanese war atrocities, integrating Japan in the Cold War order under aegis of the United States, and the ongoing legal struggle of former comfort women ${ }^{106}$ that the conceptualization and organization of prostitution as an administrative practice was a vital element to constitute the postwar myth of Japanese homogeneity and belonging. ${ }^{107}$ Hence, the conceptualization and organization of the "female floodwall" highlights the process of the postwar imagination and consolidation of the Japanese nation-state and the simultaneous disintegration of Japan's empire, or better yet, the reversion of Japan's imperial expansion: Since the early twentieth century Japan's aggressive war and colonial rule in Asia exported sex workers, sex work regulations, as well as specific notions of gender, sexuality and hygiene-often mediated through

${ }^{105}$ For the operations of fantastical oscillations between past and present, see: Joan W. Scott, "Fantasy Echo: History and the Construction of Identity," Critical Inquiry 27, no. 2 (200I): 287 .

${ }^{106}$ Leo Ching, "'Give Me Japan and Nothing Else!': Postcoloniality, Identity, and the Traces of Colonialism," The South Atlantic Quarterly 99, no. 4 (2000): 765.

107 Oguma, Tan'itsu minzoku shinwa no kigen, 339. The myth or discourse of Japanese homogeneity became particularly popular during the I 980 os and I99os, commonly subsumed under the expression nihonjinron. Peter Dale, The Myth of Japanese Uniqueness (London and Sydney: Croom Helm, I986); Kosaku Yoshino, Cultural Nationalism in Contemporary Japan: A Sociological Enquiry (London and New York: Routledge, I 992); Harumi Befu, Hegemony of Homogeneity: An Anthropological Analysis of "Nihonjinron" (Sydney: Trans Pacific Press, 200I). 
further global entanglements with the West and its colonies-that shaped the understanding of Japan's empire and Japanese imperial subjectivity. With defeat in I945, Japan's imperial dreams shattered, but imperial experiences of gender, sexuality and prostitution continued to shape ideas of Japanese belonging. This time, however, the meaning of Japan changed and one of the significant-or rather: signifying arenas to imagine the formation of a new Japan and new Japanese belonging in the immediate postwar period was the conceptualization and organization of prostitution as administrative practice. 